\title{
Industrial Energetic Districts: Impact Analysis on the Global Energy Efficiency and Business Competitiveness
}

\author{
Lesme Corredor $^{1}$, José Avendaño ${ }^{2}$, Robert Bello ${ }^{1}$, Álvaro Redondo ${ }^{1}$, José Calle ${ }^{1}$, and Jesús Viloria ${ }^{1}$ \\ ${ }^{1}$ Universidad del Norte, Barranquilla, Colombia \\ ${ }^{2}$ Gracetales S.A., Barranquilla, Colombia
}

\begin{abstract}
Process industries located in emerging economies have relative low levels of production to similar ones located in developed countries, this fact influences the implementation feasibility of cogeneration and/or tri-generation systems that allow a substantial increase in the plant global energy efficiency. In this paper, an energy and economic analysis of several alternatives of cogeneration was done for a company located in Barranquilla (Colombia, South America) that produces vegetable oils and derivatives and its energy matrix is approximately $90 \%$ thermal and $10 \%$ electric. In this investigation two type of analysis were done, both supported by process simulation software, these are: 1) Taking the plant as the control volume and evaluating the entire electrical demand supply with natural gas engine and turbine generator, plus exhaust gases heat recovery for refrigeration and/or preheating of thermal oil or water in boilers. 2) As an energy-industrial district, where the company takes advantage of the residual heat of a gas turbine and sells the excess of electrical power to nearby plants, a concept introduced by the authors as Sustainable Energetic Industrial District in Emerging Economies (SEIDEE). The input variable considered for this analysis was electric demand which restricts the technology implementation. It was found that the investment return period is notably lengthy when the thermal machine supplies the electric power demanded by the industrial plant. This period is considerably reduced when the SEIDEE concept is implemented, this period reduction is between $57 \%$ and $65 \%$.
\end{abstract}

\section{Introduction}

Industrial plants that have an energy matrix composed by electricity and thermal sources, are very attractive to analyze an eventual cogeneration and tri-generation systems implementation, this is because of the fossil fuels' high heating value. To industrial sector, these alternatives evaluation are very interesting, this will decrease electric and thermal consumption during the year. In this paper, authors evaluate gas turbine and internal combustion engine implementation, considering economic and technical aspects required by the industrial plant.

These plants have a yearly maximum electric consumption; moreover, this consumption is variable during the year, the reason why equipment and machines inside the plant must be able to work in partial and nominal conditions. Electricity produced by gas turbine and internal combustion engine is evaluated in the following scenarios:

1. Thermal machines supply electric energy, lower than maximum electric consumption. In this scenario, the plant must buy electricity, which does not develop plant self-sufficiency.

2. Thermal machines supply electric energy equal to maximum electric consumption. This scenario develops plant self-sufficiency.
3. Thermal machines supply electric energy, higher than maximum electric consumption. This scenario does not only mean plant self-sufficiency, but also will make interesting electricity sale to nearby plants, introducing the proposed concept by authors: Sustainable Energetic Industrial District in Emerging Economies (SEIDEE).

Second and third scenarios are very attractive to analyze, that is why they will be studied in detail. The first scenario is not interesting, it is because the industrial plant will depend on electric grid and electricity costs will not decrease considerably. The third scenario is the most attractive one, it provides the highest economic benefit, but is the most complex because of the technical requirements.

As well as electric consumption, industrial plants have a maximum thermal consumption which tends to be partialized in natural gas, coal or diesel; in this case the thermal consumption is totally produced by natural gas. Natural gas taxes are a very important topic in the region that is why a reduction in its consumptions will be interesting for any industry. These conditions make cogeneration and tri-generation systems implementation a seemly alternative.

Authors considered the following aspects to implement these systems:

- To identify which equipment demands the highest thermal consumption. The objective is to implement 
the proposed technologies (internal combustion engine or gas turbine) to reduce this thermal consumption.

- To analyze industrial plant electric demand fluctuation. This aspect will identify which technology satisfies technical requirements to be integrated to the industrial plant.

This article discusses cogeneration (taking advantage of energy produced by the technologies proposed to reduce natural gas consumption) and/or tri-generation (cold production using an absorption chiller) systems implementation. These alternatives will be evaluated for the second and third scenario. Economic and technical aspects will be considered and analyzed to implement the best alternative.

\section{District environment and load definition}

The performance of the industrial district in the analysis is affected by different factors that define its energy efficiency and competitiveness. The district is located in the northern coast of Colombia, specifically in the city of Barranquilla. The average temperature of this region is $33^{\circ} \mathrm{C}$ and the relative humidity of air $82 \%$ [1]. Adding to these, the power demand of the plant is notably variable, something that depends on the season and the requirements of clients. For this reason, it is possible to observe that the maximum power consumed in a month is $910 \mathrm{kWhe}$, while the average demand of the plant is 785 $\mathrm{kWhe}$. This demand is not so significant in comparison to the consumption of thermic energy that this district uses in its productive process. The following figures show the hourly behavior of electric energy demand in twelve months in a specific year.

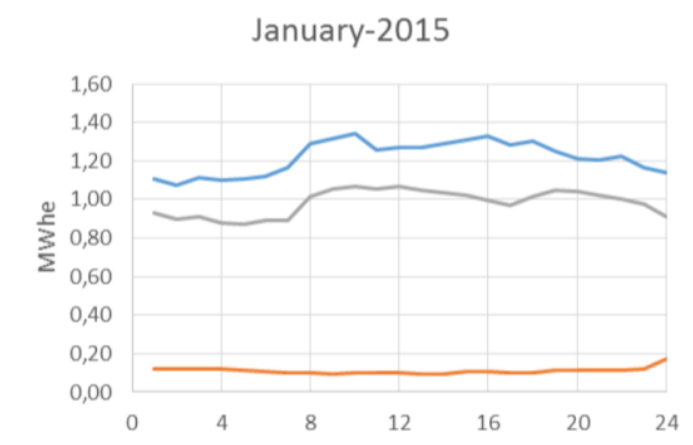

Fig. 1. Hourly electric consumption profiles for January.

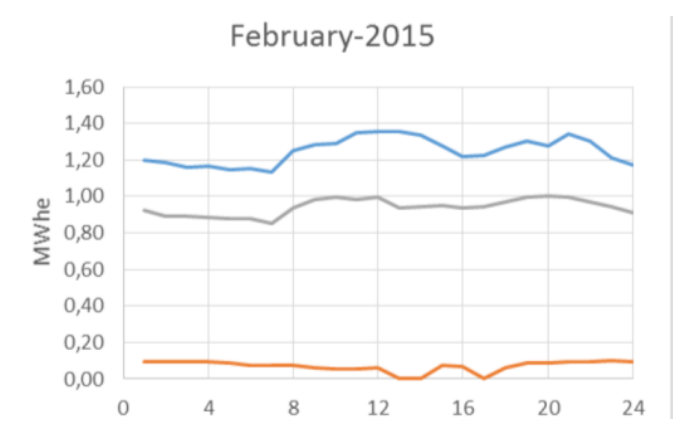

Fig. 2. Hourly electric consumption profiles for February.

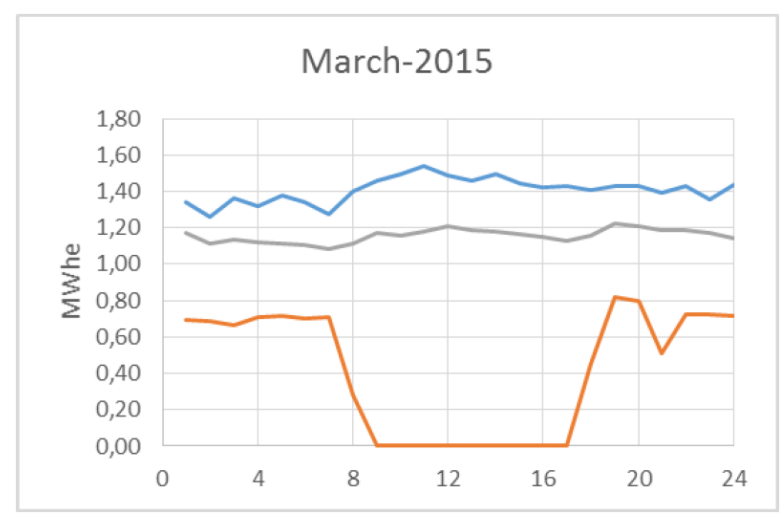

Fig. 3. Hourly electric consumption profiles for March.

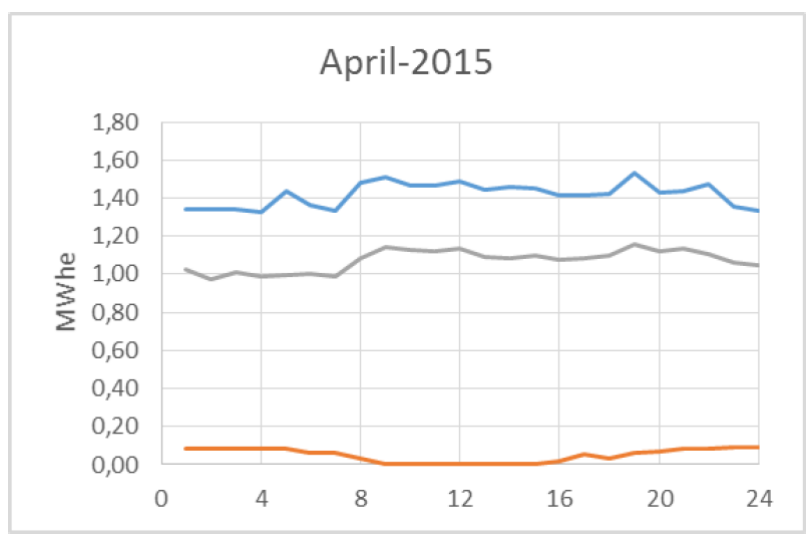

Fig. 4. Hourly electric consumption profiles for April.

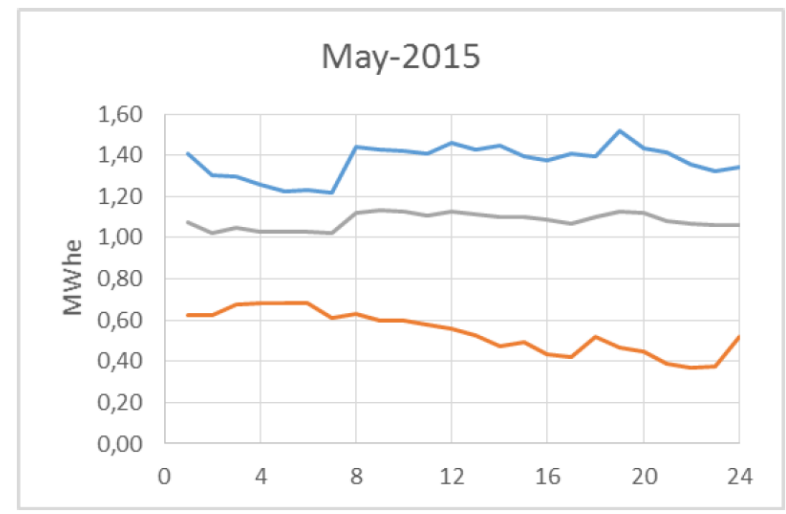

Fig. 5. Hourly electric consumption profiles for May.

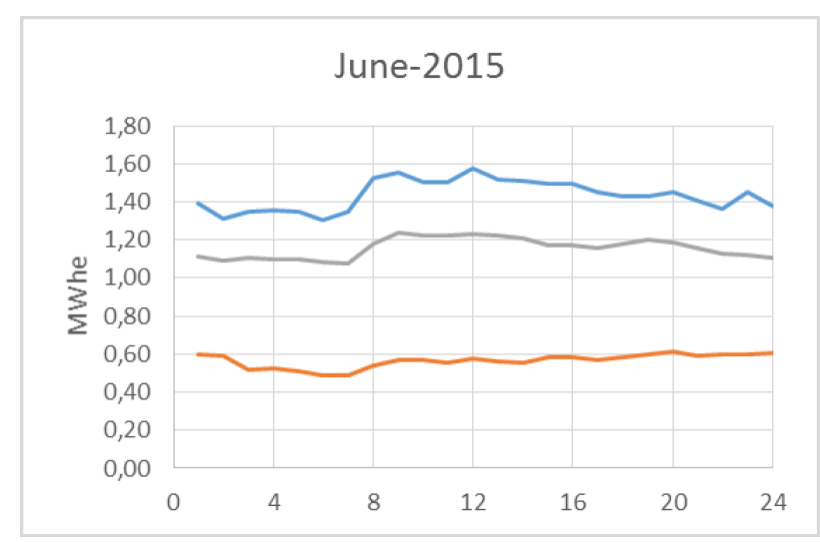

Fig. 6. Hourly electric consumption profiles for June. 


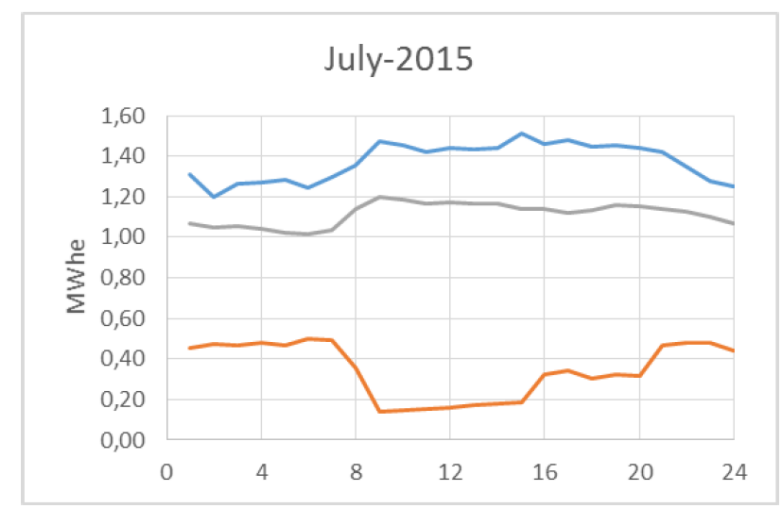

Fig. 7. Hourly electric consumption profiles for July.

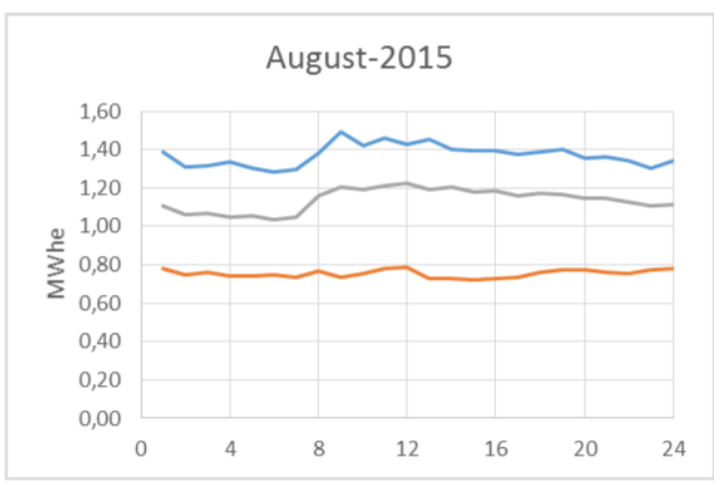

Fig. 8. Hourly electric consumption profiles for August.

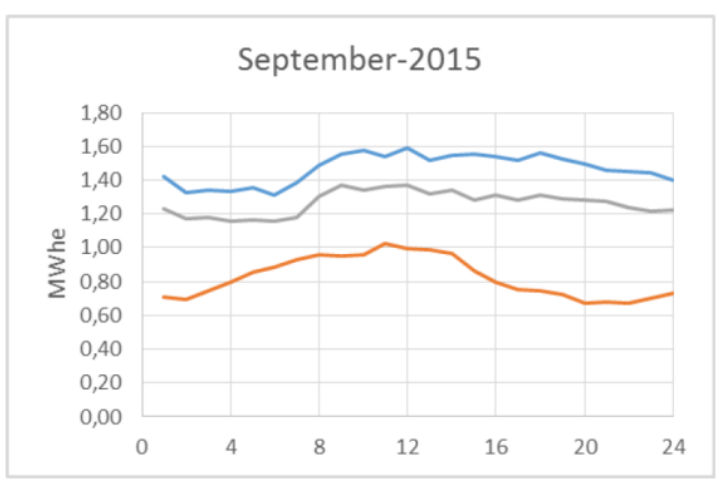

Fig. 9. Hourly electric consumption profiles for September.

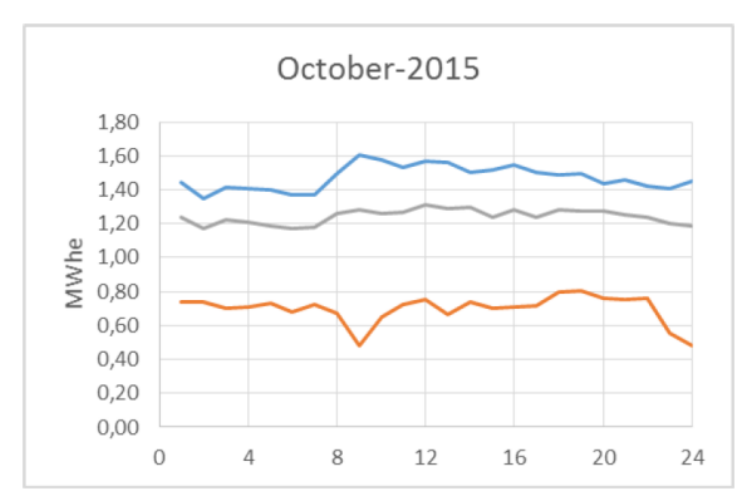

Fig. 10. Hourly electric consumption profiles for October.

For the following group of figures from Figure 1 to Figure 12, the colors presented in the graphs correspond to:
- Orange stripe: hourly minimum consumption registered in the month.

- Blue stripe: hourly maximum consumption registered in the month.

- Gray stripe: hourly consumption for a characteristic day in the month.

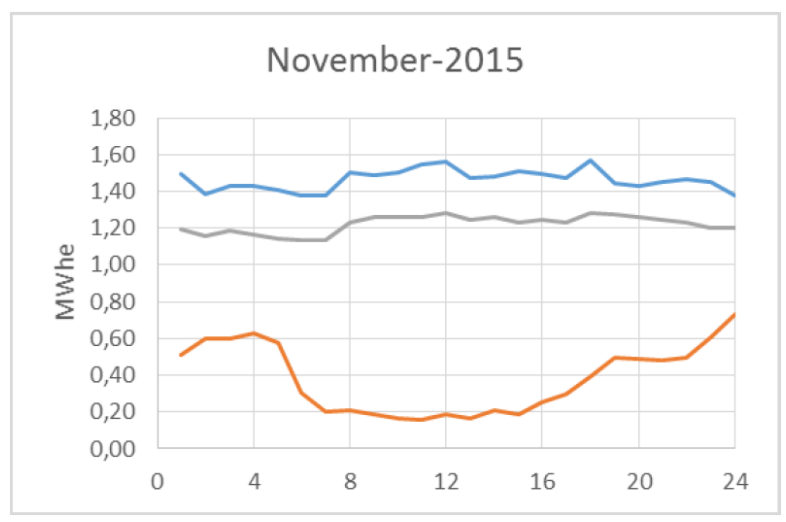

Fig. 11. Hourly electric consumption profiles for November.

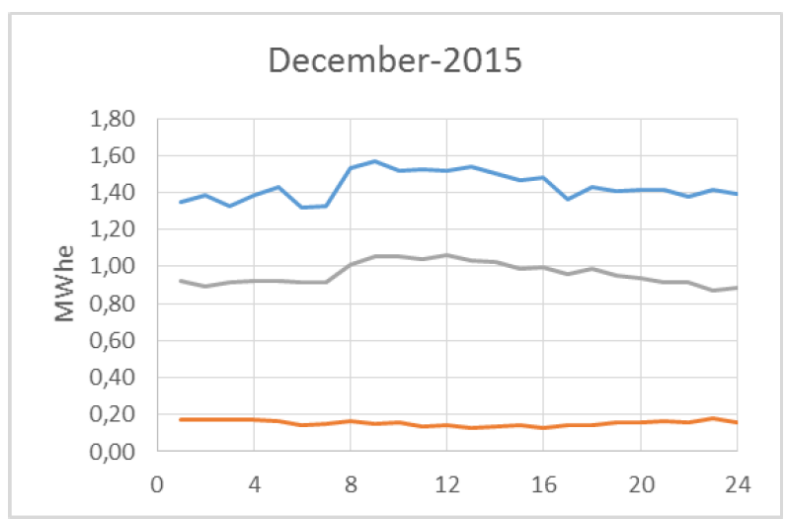

Fig. 12. Hourly electric consumption profiles for December.

The thermic energy demand of this district reaches a $90 \%$ in relation to the total energy consumed by the plant. The highest demands present when clients make high requirements reaching a monthly consumption of $17,054 \mathrm{kWht}$ and an average consumption for this same period is $14,850 \mathrm{kWht}$.

\section{Problem statement}

Searching for improved energy efficiency and to raise the competitiveness of the plant, the analysis of the implementation of power generation systems turns into an interesting alternative. The high demand of thermic energy that the district shows, leads to considerate it as a "thermal host". The area where the company is located turns into a potential client for generated power since the neighbors are plants with similar consumptions to this district. Therefore, the implementation of cogeneration and tri-generation technologies appear to be viable alternatives.

The implementation of these technologies is tied to variables such as the behavior of energy requirements, the place where they are to be installed and prices of 
natural gas. To implement these systems, it is necessary to carry out corresponding studies and select the most favorable configuration taking into consideration the interests of the project.

\section{Historical background}

In Colombia, the tendency to start implementing cogeneration technology or at least to study its viability has spread in several companies. This is why a large number of companies have been found that have dared to investigate and investigate how this technology works and how it would impact its costs. The most representative is the experience lived on behalf of the pasta company Doria. In this company a cogeneration system was implemented in which an internal combustion engine based on natural gas is used as a thermal machine. In this company as in many others there is the problem in production times as a consequence of the instability of the public service network. Due to this the installation of the cogeneration system with a Cummins gas engine with a capacity of $1,750 \mathrm{~kW}$ was evaluated. With which it is able to supply the thermal demand of the plant and additionally generate electricity.

Thanks to this system implemented by the aforementioned company, savings of $60 \%$ have been achieved in the purchase of electricity to the public grid and, most importantly, the electricity generated is highly reliable. And in terms of fossil fuels, the company has improved its fuel consumption achieving savings of $70 \%$ which also translates into $\$ 50,000$ a month in energy costs. The most interesting of this is that the motorgenerator system works 24 hours increases the productive times of the company [1].

Other companies have opted to start similar to the one that was presented by Pastas Doria. Companies like Empacor, Corona, Monómeros have dared to bet on this technology not only for the benefits it brings but also because it becomes much more profitable from the economic point of view in addition to contributing to the reduction of $\mathrm{CO} 2$ emissions towards the atmosphere. Finally, no evidence has been found that within all of the aforementioned companies an energy district is developed. In this article, the authors propose the development of an industrial energy district, which increases the efficiency of the cogeneration process and additionally increases the reliability of the electrical energy generated by a thermal machine [7].

\section{Simulation specifications}

To simulate, the conversion from ISO conditions was made to analyze the expected performance of the machines in the correspondent room temperature $\left(35^{\circ} \mathrm{C}\right)$. Calculations of important engineering variables and the study of the systems in general were all made using the datasheets from the equipment in use. To calculate, it was assumed that electric demand values are equal to industrial plant instantaneous power; it is because there is no power measurement. In order to select the most suitable thermal machines (in terms of capacity), electric demand profile was directly taken from company's consolidate.

Flows, temperatures, pressures and other thermodynamic variables used to simulate were provided by the company. This information will not be mentioned in this paper because of confidentiality terms. All data used to simulate thermal machines proposed was extracted directly from manufacturers' datasheet.

To evaluate new technology incorporation to the process, authors used Aspen HYSYS $®$. The software models industrial processes and was used to simulate operational equipment conditions. The equipment which demands the highest thermal consumption in the industrial plant is a $75,000 \mathrm{lb} / \mathrm{h}$ Nebraska ${ }^{\circledR}$ boiler. Its consumption represents an $85 \%$ of the plant thermal demand. The following figure shows the boiler simulation.

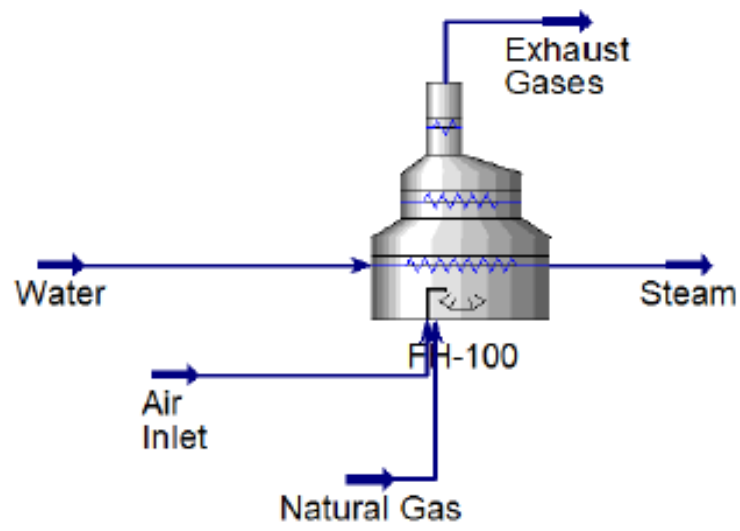

Fig. 13. Boiler simulation.

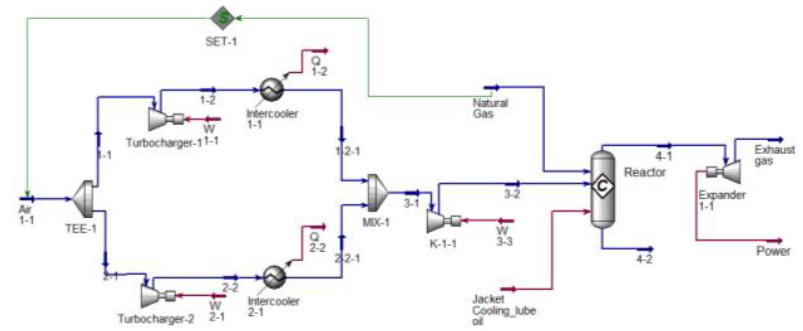

Fig. 14. Internal combustion engine simulation.

A natural gas internal combustion engine implementation is an alternative proposed. The internal combustion engine was analyzed in three cases:

1. Internal Combustion Engine Cummins ${ }^{\circledR} 1,000$ N6C [3] to implement a cogeneration system (Scenario $1)$.

2. Internal Combustion Engine Deutz ${ }^{\circledR} 1,600$ TCG 2,020 [4] to implement a cogeneration system (Scenario 2).

3. Internal Combustion Engine Deutz ${ }^{\circledR} 1,600$ TCG 2,020 [4] to implement a tri-generation system (Scenario 2).

To simulate internal combustion engines, authors used [5]. The following figures show Cummins ${ }^{\circledR}$ engine 
simulation and engine efficiency vs natural gas mass flow.

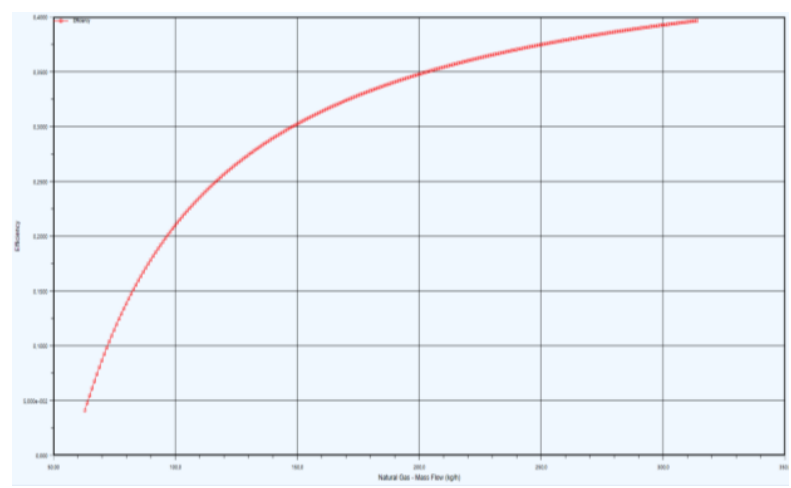

Fig. 15. Internal combustion engine efficiency vs natural gas mass flow $(\mathrm{kg} / \mathrm{h})$.

Natural gas turbine is the other alternative proposed for the analysis. The following, are the three cases evaluated to this thermal machine.

1. Solar Turbines ${ }^{\circledR}$ Saturn 20 [11] to implement a trigeneration system (Scenario 2).

2. Solar Turbines ${ }^{\circledR}$ Centaur 50 [10] to implement a tri-generation system (Scenario 3).

3. Solar Turbines ${ }^{\circledR}$ Taurus 70 [12] to implement a trigeneration system (Scenario 3).

To the simulation, the article [9] was used as a guide. The following figure shows the simulation.

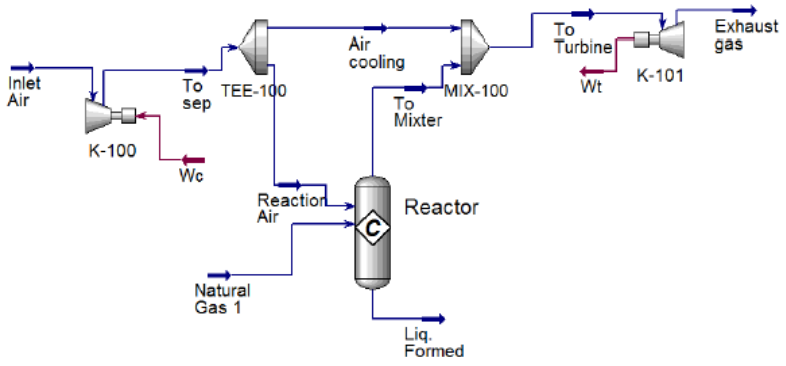

Fig. 16. Gas turbine simulation.

An absorption chiller implementation, which will supply the cold demand required by the plant was considered in this paper. Therefore, two Thermax ${ }^{\circledR}$ absorption chillers were considered, the first one has a capacity of 296TR and the other 501TR [13].

\section{Configuration}

To obtain energetic indicators of the process and to analyze the new technology performance, it is necessary to develop a configuration that includes a relationship between all the equipment mentioned before. This relationship could be by heat recovery systems or by power supply. Because of the viability of the project, it is important to define it by the prior items. Real equipment simulation is obligatory and some relevant information of them is presented in Table 1 and Table 2.

Table 1. Simulated and real gas turbines comparison.

\begin{tabular}{|c|c|c|c|c|c|c|}
\hline & \multicolumn{6}{|c|}{ SOLAR GAS TURBINES® } \\
\hline & \multicolumn{3}{|c|}{ Output Power (kW) } & \multicolumn{3}{|c|}{ Exhaust Temperature (K) } \\
\hline & Datasheet & Simulated & Deviation & Datasheet & Simulated & Deviation \\
\hline Saturn ${ }^{\circledR} 20$ & 1100 & 1160 & $5,455 \%$ & 778,1 & 834,5 & $7,248 \%$ \\
\hline Centaur ${ }^{\circledR} 50$ & 4000 & 4028 & $0,700 \%$ & 783,1 & 788,6 & $0,702 \%$ \\
\hline Taurus $^{\mathrm{TM}} \mathbf{7 0}$ & 6600 & 6624 & $0,364 \%$ & 778,1 & 746 & $-4,125 \%$ \\
\hline
\end{tabular}

Table 2. Simulated and real internal combustion engines comparison.

\begin{tabular}{|c|r|r|r|r|r|r|}
\cline { 2 - 7 } \multicolumn{1}{c|}{} & \multicolumn{6}{c|}{ INTERNAL COMBUSTION ENGINE } \\
\cline { 2 - 7 } & \multicolumn{3}{c|}{ Output Power (kW) } & \multicolumn{3}{c|}{ Exhaust Temperature (K) } \\
\cline { 2 - 7 } & Datasheet & Simulated & Deviation & Datasheet & Simulated & Deviation \\
\hline Cummins ${ }^{\circledR 1000}$ & 1031 & 979,6 & $-4,985 \%$ & 687 & 697,7 & $1,557 \%$ \\
\hline Deutz ${ }^{\circledR 1600}$ & 1555 & 1402 & $-9,839 \%$ & 713 & 776,3 & $8,878 \%$ \\
\hline
\end{tabular}

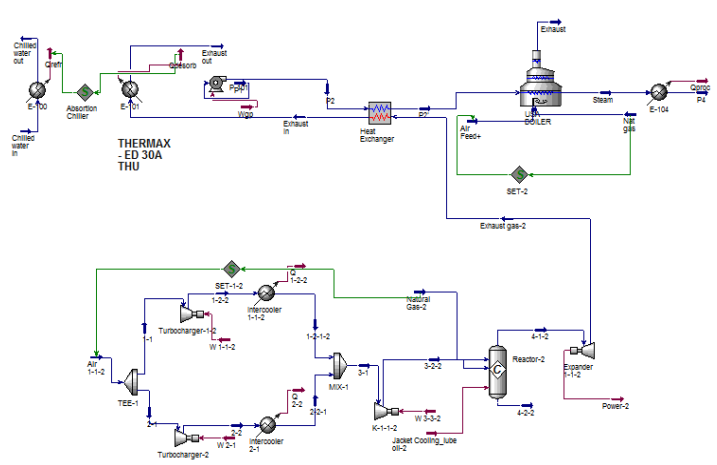

$\underset{\substack{\text { DEUTZ- } \\ \text { ICG62020 } \\ \text { V16 }}}{\operatorname{Cos}}$

Fig. 17. Industrial plant with a tri-generation system composed by a 1.6 MW internal combustion engine and a 296TR absorption chiller.

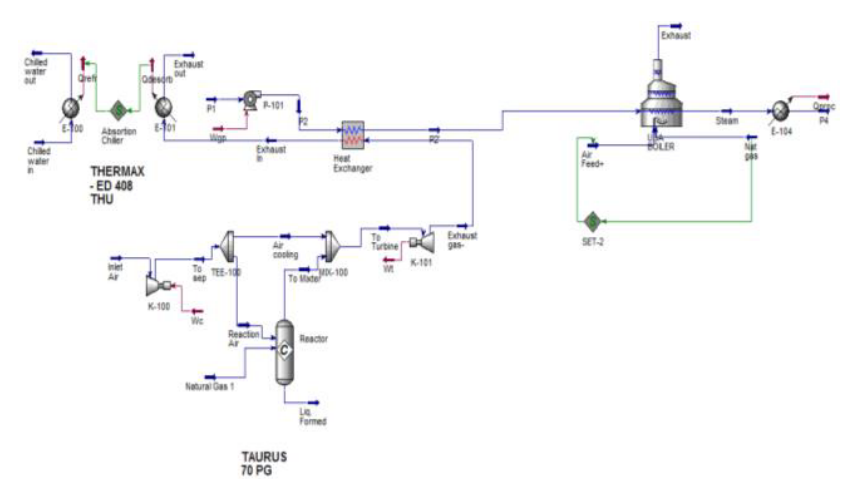

Fig. 18. Industrial plant with a tri-generation system composed by an $8 \mathrm{MW}$ gas turbine and a 501TR absorption chiller. 
Taking the equipment information as the base, a configuration of them has been proposed taking a positive performance as the main consideration for the implementation. The composition of each configuration is presented in the following figures.

The following figures present the configuration for the third case using an internal combustion engine (Deutz ${ }^{\circledR}$ TCG2020 V16 Internal Combustion Engine and 296 TR Thermax ${ }^{\circledR}$ Absorption Chiller).

In addition, the next figure shows the configuration with the implementation of the third case of gas turbine (Solar 6 Turbines ${ }^{\circledR}$ Taurus 70 and 501TR Thermax ${ }^{\circledR}$ Absorption Chiller).

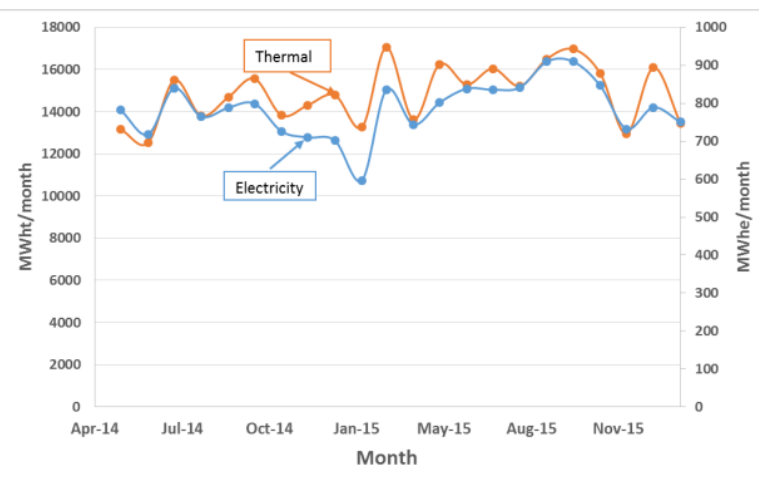

Fig. 19. Energetic demand profile.

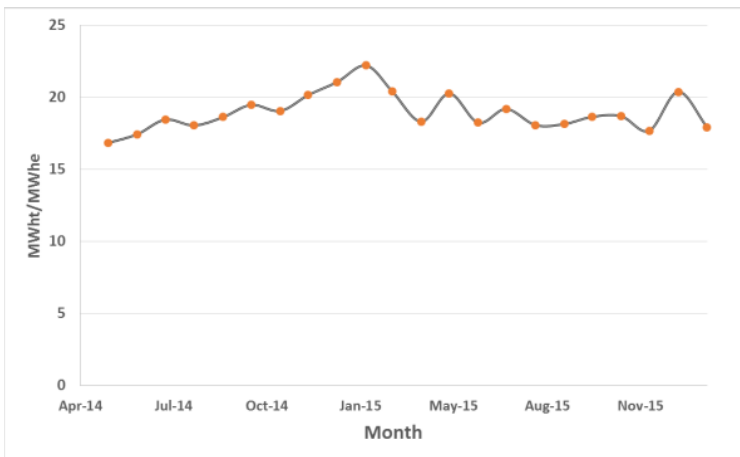

Fig. 20. Energetic indicator: Thermal and electric consumption ratio.

\section{Statistic analysis}

The charge simultaneity and the statistic superposition between the thermal and electrical demand are not considered in this paper. The reason is that the data registers available have been presented for different periods of time where the thermal demand ( $\mathrm{Nm} 3$ of natural gas consumed) is registered month by month and the electrical consumption is presented hour by hour. In addition, the company shared data of a short period of time (May 2014 to February 2015) and this leads to the no application of statistical analysis by stochastic methods that generates a great reliability on the energetic demand of the firm. Sau Man Lai and Chi Wai Hui propose this method [8]. For this analysis, the electric consume behavior play the main roll. Because of the interests for this work, the electric demand is presented showing the maximums and minimums points of the electric and thermal consumption for each hour of the months that are under analysis (2015). It includes the atypical data produced by the energy interruption by the local supplier company. Besides, this paper analyses occurrence deleting the aberrant data. For this, representative data is selected for each hour and then the consume profile is developed to represent each month with a confidence of $60 \%$. The electrical data is presented as energy consumption in kWhe. For practical purposes, constant energy consumptions are assumed for each hour. Energy consumption profiles are presented in the following pictures.

\section{Cost analysis}

For the cost analysis of the plant, the 3 different scenarios were studied taking into consideration the possibilities of implementing the 2 different technologies: gas turbine and internal combustion engine Actual prices for electricity and gas were obtained directly from the company to calculate potential savings. It is important to mention that available heat recovered was assumed to be used at maximum, later studies about companies' privacy would later need to be studied.

To calculate the costs of the different projects approximations were made using values from CHP's characterization of turbines and engine technologies [2]. The costs calculated on the project in study were later converted into present value assuming an annual inflation of $3 \%$ in USD till year 2016. The following table shows the costs approximated by the American entity and used in the current document:

Table 3. Combustion engine project approximate costs.

\begin{tabular}{|c|c|c|c|}
\hline \multicolumn{4}{|c|}{ Combustion Engine Project Approximate Costs } \\
\hline $\begin{array}{c}\text { Capacity } \\
{[\mathbf{k W}]}\end{array}$ & 500 & 1000 & 3000 \\
\hline $\begin{array}{c}\text { Project Cost } \\
{[\text { \$USD/kW] }}\end{array}$ & 1940 & 1640 & 1130 \\
\hline $\begin{array}{c}\text { Maintenance } \\
\text { Costs } \\
\text { [\$USD/kWh] }\end{array}$ & 0.016 & 0.013 & 0.01 \\
\hline
\end{tabular}

Table 4. Gas turbine project approximate costs.

\begin{tabular}{|c|c|c|c|}
\hline \multicolumn{4}{|c|}{ Gas Turbine Project Approximate Costs } \\
\hline $\begin{array}{c}\text { Capacity } \\
{[\mathbf{k W}]}\end{array}$ & 1000 & 5000 & 10000 \\
\hline $\begin{array}{c}\text { Project Cost } \\
\text { [\$USD/kW] }\end{array}$ & 3324 & 1314 & 1298 \\
\hline $\begin{array}{c}\text { Maintenance } \\
\text { Costs } \\
\text { [\$USD/kWh] }\end{array}$ & 0.0111 & 0.0074 & 0.007 \\
\hline
\end{tabular}

To summarize the whole economic analysis, the results will show: A) The approximate investment calculated for the project in study. These costs are a safe gross approximation to evaluate the viability of the project. B) The potential annual savings calculated taking into consideration heat recovery, refrigeration, power 
sale and others depending on the case. C) The capital investment return in years. D) The Internal Return Rate calculated on a life of 10 years. The detailed results of the project could not be showed because of confidentiality matters with the company.

As mentioned before the first scenario was analyzing the possibility of generating electricity below the companies' consumption needs. A Cummins ${ }^{\circledR} 1,000 \mathrm{~kW}$ engine [3] was used to study this scenario, where potential heat recovery was analyzed (cogeneration). The company would still need to buy electricity from the market to supply their needs when consumption is high, so the statistical data was used to approximate these costs (frequency of occurrence). The following table shows the results for the first scenario:

Table 5. Cost results scenario 1 .

\begin{tabular}{|c|c|}
\hline \multicolumn{2}{|c|}{ Co-generation Cummins ${ }^{\circledR} \mathbf{1 0 0 0} \mathbf{~ k W}$} \\
\hline Gas Consumption [m//h] & 248.5 \\
\hline Electrical Output [kW] & 948.22 \\
\hline Electrical Efficiency & $41.55 \%$ \\
\hline Recovered Heat [kW] & 802.5 \\
\hline $\begin{array}{c}\text { Monthly Electrical Power } \\
\text { Supply [MWh] }\end{array}$ & 2250.6 \\
\hline $\begin{array}{c}\text { Approximate Project Cost } \\
\text { [k\$USD] }\end{array}$ & 3529 \\
\hline $\begin{array}{c}\text { Potential Annual Savings } \\
\text { [k\$USD] }\end{array}$ & 387.88 \\
\hline Investment Return [years] & 9.1 \\
\hline Internal Rate of Return & $4.63 \%$ \\
\hline
\end{tabular}

Table 6. Cost results scenario 2 .

\begin{tabular}{|c|c|c|c|}
\hline & $\begin{array}{c}\text { Co-generation } \\
\text { Deutz® 1600 }\end{array}$ & $\begin{array}{c}\text { Tri-generation } \\
\text { Deutz® 1600 }\end{array}$ & $\begin{array}{c}\text { Tri-generation } \\
\text { Saturn® 20 }\end{array}$ \\
\hline $\begin{array}{c}\text { Gas } \\
\text { Consumption } \\
{[\mathbf{m 3 / h}]}\end{array}$ & 306.1 & 286.1 & 472 \\
\hline $\begin{array}{c}\text { Electrical } \\
\text { Efficiency }\end{array}$ & $38.81 \%$ & $38.81 \%$ & $23.53 \%$ \\
\hline $\begin{array}{c}\text { Recovered } \\
\text { Heat [kW] }\end{array}$ & 962 & 469.3 & 677 \\
\hline $\begin{array}{c}\text { Refrigeration } \\
\text { Max [kW] }\end{array}$ & $\mathrm{N} / \mathrm{A}$ & 1,041 & 1,762 \\
\hline $\begin{array}{c}\text { Approximate } \\
\text { Project Cost } \\
\text { [kSUSD] }\end{array}$ & 4,631 & 5,085 & 7,061 \\
\hline $\begin{array}{c}\text { Potential } \\
\text { Savings } \\
\text { [kSUSD/y] }\end{array}$ & 547.7 & 308.3 & 258 \\
\hline $\begin{array}{c}\text { Investment } \\
\text { Return [years] }\end{array}$ & 8.46 & 16.49 & 27.39 \\
\hline $\begin{array}{c}\text { Internal Rate } \\
\text { of Return [10 } \\
\text { y] }\end{array}$ & $5.93 \%$ & $-10.18 \%$ & $-19.28 \%$ \\
\hline
\end{tabular}

The numbers do not seem to be too attractive for this alternative, mainly because fuel consumptions end making the operation expensive which shows that low power cogeneration is not viable with the high gas prices present in the region.

In the second scenario, the possibility of generating the maximum electric needs of the company was analyzed. In this scenario 3 cases were studied, the possibility cogeneration and tri-generation with Deutz ${ }^{\circledR}$ $1,600 \mathrm{~kW}$ [4] engine and tri-generation with Solar
Turbines ${ }^{\circledR} \quad$ Saturn 20 [11]. A $\quad$ Thermax ${ }^{\circledR} \quad 300$ refrigeration tons Absorption Chiller was used for the engine's case while a 500 RT was use for the gas turbine (this one would satisfy the whole refrigeration needs) [13]. Refrigeration data

Having to work at partial load, the engine's cases were analyzed with data from the original datasheet and frequencies of operation obtained from statistical data. The frequencies of operation were used to approximate engineering variables such as fuel consumption, and therefore to calculate corresponding costs.

Results for Cogeneration with Deutz ${ }^{\circledR}$ engine are far more satisfactory than tri-generation ones. The reasons for this are the low refrigeration needs of the company and the high costs of turbines compared to engines. The results of the scenario for the turbine let us see that in general the low scale of the plant does not help on the economical aspect of the project. Turbines tend to be inefficient when designed for low power values, which is of course the problem in the studied case. This problem results in high gas consumptions for low power availability which leads to a non-viable investment. Still for all cases of scenario 2, numbers do not sum up (Cogeneration returns at least positive income values). Adding to these the electrical demand of the company is not constant at all, which does not benefit the Turbines operation since it is technically vulnerable to abrupt power changes.

Finally, in the third scenario, the implementation of a Sustainable Energetic Industrial District in Emerging Economies (SEIDEE) is introduced. A SEIDEE is defined by authors as a small power generator inside a city that could supply power to nearby companies. This power generator company will be a "thermal host" that can take advantage of thermic energy to generate electricity in excess to sell at discount prices to nearby users.

For this final scenario, only gas turbines are used because of their good efficiency at higher loads. Specifically, cases with Solar Turbines ${ }^{\circledR}$ Centaur 50 [10] and Taurus ${ }^{\mathrm{TM}} 70$ [12] were analyzed. For this scenario, the possibility of selling power to nearby companies was studied taking into consideration a probable sale with a $15 \%$ discount on commercial value (from 320 to $270 \$ C O P / \mathrm{kWh}$ or 0.1 to $0.0844 \$ \mathrm{USD} / \mathrm{kWh})$. Comparisons between a regular sale (Approx. $0.047 \$ \mathrm{USD} / \mathrm{kWh}$ ) and a sale in what a SEIDEE would allow are showed in tables below for each case. Values of consumption, efficiency, recovered heat and others do not change for the SEIDEE proposal, just the price of a $\mathrm{kWh}$.

Table 7. Cost results scenario 3 .

\begin{tabular}{|c|c|c|}
\hline $\begin{array}{c}\text { Regular } \\
\text { Generation }\end{array}$ & $\begin{array}{c}\text { Tri-generation } \\
\text { Centaur }{ }^{\circledR} \mathbf{5 0}\end{array}$ & $\begin{array}{c}\text { Tri-generation } \\
\text { Taurus }^{\text {TM 70 }}\end{array}$ \\
\hline $\begin{array}{c}\text { Gas Consumption } \\
{[\mathbf{N m} \text { / } / \mathbf{h}]}\end{array}$ & 1,368 & 2,112 \\
\hline $\begin{array}{c}\text { Electrical Output } \\
{[\mathbf{k W}]}\end{array}$ & 3,800 & 6,600 \\
\hline $\begin{array}{c}\text { Electrical } \\
\text { Efficiency }\end{array}$ & $28.57 \%$ & $32 \%$ \\
\hline
\end{tabular}




\begin{tabular}{|c|c|c|}
\hline $\begin{array}{c}\text { Recovered Heat } \\
{[\mathbf{k W}]}\end{array}$ & 4,091 & 5,942 \\
\hline $\begin{array}{c}\text { Refrigeration } \\
\text { Max[kW] }\end{array}$ & 1,762 & 1,762 \\
\hline $\begin{array}{c}\text { Revenue for Power } \\
\text { Sale [k\$USD/y] }\end{array}$ & 882 & 1,789 \\
\hline $\begin{array}{c}\text { Approximate } \\
\text { Project Cost } \\
\text { [k\$SD] }\end{array}$ & 13,106 & 79,628 \\
\hline $\begin{array}{c}\text { Potential Savings } \\
\text { [k\$USD/y] }\end{array}$ & 497.56 & 26.58 \\
\hline $\begin{array}{c}\text { Investment Return } \\
\text { [years] }\end{array}$ & 26.34 & $-21.69 \%$ \\
\hline $\begin{array}{c}\text { Internal Rate of } \\
\text { Return }\end{array}$ & $-20.73 \%$ & \\
\hline
\end{tabular}

Table 8. Cost results scenario 3 SEIDEE.

\begin{tabular}{|c|c|c|}
\hline SEIDEE & $\begin{array}{c}\text { Tri-generation } \\
\text { Centaur }{ }^{\circledR 50}\end{array}$ & $\begin{array}{c}\text { Tri-generation } \\
\text { Taurus }^{\text {TM 70 }}\end{array}$ \\
\hline $\begin{array}{c}\text { Revenue for Power } \\
\text { Sale [k\$USD/y] }\end{array}$ & $1,587.8$ & 3,220 \\
\hline $\begin{array}{c}\text { Potential Savings } \\
{[\mathbf{k \$ U S D / y ]}}\end{array}$ & $1,203.2$ & 2,170 \\
\hline $\begin{array}{c}\text { Investment Return } \\
\text { [years] }\end{array}$ & 11.23 & 9.05 \\
\hline $\begin{array}{c}\text { Internal Rate of } \\
\text { Return }\end{array}$ & $-0.98 \%$ & $3.57 \%$ \\
\hline
\end{tabular}

Economic results end up being not that promising as expected mainly because as mentioned before the low scale of power generation does not allow the turbines to perform at high efficiencies. Nevertheless, a big improvement is seen when selecting the Taurus ${ }^{\mathrm{TM}} 70$ and selling electricity close to commercial value. Therefore, the important variables are the price of sold $\mathrm{kWh}$ and the cost of natural gas consumption.

High prices of natural gas and low prices for the electric selling market do not allow numbers to show the real potential of tri-generation systems. These problems are characteristic from the region, and this is the reason the authors propose the creation of SEIDEE's in the city to encourage the implementation of cogeneration and trigeneration systems that will increase energy efficiency in the region and off course reduce contaminating emissions. Different governmental policies such as lower gas consumption tariffs, higher power generation incentives, tax reductions, and the creation of an open electrical market would all increase chances of a satisfactory implementation of these systems in the Caribbean coast of Colombia.

\section{Conclusions}

The first scenario proposed by authors is not interesting to industrial plants. Internal combustion engine supplies an electric demand fraction and the investment return period is lengthy. Moreover, the plant will still depend on electric grid. In the second scenario, in which the plant is self-sufficient, the investment return period is also lengthy, this is not an acceptable condition for companies in the region because it represents a high investment. These periods are restricted by the plant low-production levels, which impact directly the electric consumption; if the plant had a higher electric consumption, the investment return period would be shorter. Furthermore, industrial plant electric consumption is very variable during its operation, restricting proposed technologies. When the gas turbine is evaluated, these permanent variations in electric demand will represent demanding operational conditions that will shorten its lifetime; this will not allow its implementation. Referring to trigeneration, industrial plant cold production is mediumhigh, but this production is not constant, this condition will reduce absorption chiller performance, reason for which authors propose a cold-water storage tank, that ensures a constant cold production.

The third scenario is the most important, some interesting results were found. The investment return period is notably reduced when the concept introduced by authors (SEIDEE) is implemented, reducing this period between $57 \%$ and $65 \%$. For this scenario, gas turbine will be the most suitable technology when SEIDEE is implemented. To get a shorter investment return period, the gas turbine must generate a greater electric power than the gas turbine analyzed (Solar Turbines ${ }^{\circledR}$ Taurus 70 ). Another reason that makes gas turbine more reliable than internal combustion engine, is that gas turbine will supply all the energy required by the energetic district. Finally, internal combustion engine is the most suitable thermal machine for this project, it is more inexpensive than gas turbine which represents the shortest investment return period and it can operate reliably when the industrial plant electric consumption fluctuates.

\section{Acknowledgment}

To all the work team it was a real pleasure that the industrial plant opened their doors, to meet and to practice all the knowledges referred to their processes and equipment.

Engineers Carlos Silva, Adalberto Salazar, Fabrizio Llinás and Rafael Percy, for their help in the execution of activities that end up in the development of this paper.

\section{References}

1. Características Climatológicas de Ciudades Principales y Municipios Turísticos, "Documento IDEAM", 2016.

2. Combined Heat and Power Partnership, "Catalogue of CHP Technologies", 2008.

3. Cummins Power Generation, "C1000 Generator Set Datasheet", 2015.

4. Deutz, "TCG 2020 The Gas Engine", 2015.

5. Ekwonu, M. C., Perry, S., \& Oyedoh, E. A. (2013). Modelling and Simulation of Gas Engines Using Aspen HYSYS. Journal of Engineering Science and Technology, 6(3), 1-4. 
6. Gasnaturalfenosa.com.co. (2016). Cogeneración. [online]

Available

at:

http://www.gasnaturalfenosa.com.co/co/grandes+clie ntes/soluciones+energeticas/1297102582386/cogene racion.html [Accessed 18 Nov. 2016].

7. La Republica. (2014). Con cogeneración, las empresas reducen $50 \%$ el gasto de energía. [online] Available at: http://www.larepublica.co/concogeneraci $\% \mathrm{C} 3 \% \mathrm{~B} 3 n$-las-empresas-reduce-50-elgasto-de-energ\%C3\%ADa_153511 [Accessed 18 Nov. 2016]

8. Lai, S. M., \& Hui, C. W. (2009). Feasibility and flexibility for a trigeneration system. Energy, 34(10), 1693-1704.
9. Saddiq, H. A., Perry, S., Ndagana, S. F., \& Mohammed, A. MODELLING OF GAS TURBINE AND GAS TURBINE EXHAUST AND ITS UTILISATION AS COMBINED CYCLE IN UTILITY SYSTEM.

10. Solar Turbines, "Centaur 50

11. Solar Turbines, "Saturn 20 Gas Generator set", 2013.

12. Solar Turbines, "Taurus 70 Gas Generator set", 2013.

13. Thermax, "Multi-energy Vapour Absorption Machines" Catalogue, 2016. 